Proc. Indian Acad. Sci. (Earth Planet. Sci.), Vol. 93, No. 1, March 1984, pp. 57-69.

(C) Printed in India.

\title{
Geochemistry and petrogenetic evolution of the diatexites of Central Kerala, India
}

\author{
P K RAJAN, M SANTOSH and K K RAMACHANDRAN \\ Centre for Earth Science Studies, Post Box No. 2235, Trivandrum 695010, India
}

MS received 17 February 1983 ; revised 28 July 1983

\begin{abstract}
The hornblende-biotite gneisses of Central Kerala which cover approximately $490 \mathrm{~km}^{2}$ exhibit schlieric and nebulitic structures, tending towards a homophanous nature and are classified here as diatexites. Mafic protoliths and restite biotite, each representing the refractory residuum of two independent partial melting episodes are widely present in the gneisses. The general mineral assemblage of the gneisses comprise quartz, K-feldspar, oligoclase, biotite and hornblende. Chemically, they are dominantly adamellitic and the behaviour of major and trace elements is consistent with a magmatic parentage. Based on petrochemical criteria, a two-stage evolution model is proposed here, which involves (i) partial melting of mafic granulites under high Archean geothermal gradients and generation of tonalite/trondhjemite through amphibole and plagioclase fractionation and (ii) partial melting and subsequent quartz-alkali feldspar fractionation of the tonalite/trondhjemite under amphibolite facies conditions with synchronous $\mathrm{K}$-enrichment resulting in the diatectic adamellites.
\end{abstract}

Keywords. Diatexites; protoliths; petrochemistry; partial melting; two-stage evolution; Central Kerala.

\section{Introduction}

A significant portion of the Indian shield is occupied by the so-termed 'unclassified granites and gneisses'. In Kerala, the hornblende-biotite gneisses (composite gneisses) form two major bodies in the central and northern regions. The gneissic body of Central Kerala, which is studied here, covers about $490 \mathrm{~km}^{2}$ having a rough NW-SE elongation. It occurs in the granulitic mobile belt, along a major lineament defined by the straight course of the Periyar river (figure 1). The other dominant rock type associated with the gneisses. are the charnockites with which the former shows gradational, irregular and sharp contacts. Dykes of dolerite and gabbro traverse both the gneisses and charnockites. Regarding the origin of the gneisses of the Western Ghat region in general, Mahadevan (1964) suggested that they may be the products of retrogressive metamorphism of associated charnockites.

Structurally, the crystalline rocks of Central Kerala are polyphasedly deformed. The earliest generation of folds $\left(F_{1}\right)$ are tight isoclinal folds with $\mathrm{E}-\mathrm{w}$ axial orientation. On a regional scale, fairly tight isoclinal folds with NW-sE axial trends, represent the second generation $\left(F_{2}\right)$ whose orientation has been modified by the folds of third generation. The third generation fold system is manifested in the form of large upright synforms and antiforms whose axial traces trend NNW-SSE. The dominant fracture pattern identified in the study area are NW-SE and NE-SW trending systems which are probably conjugate pairs (Santosh 1981; Santosh and Rajan 1982).

Lack of geochronological data is a severe handicap in the knowledge of the Kerala 


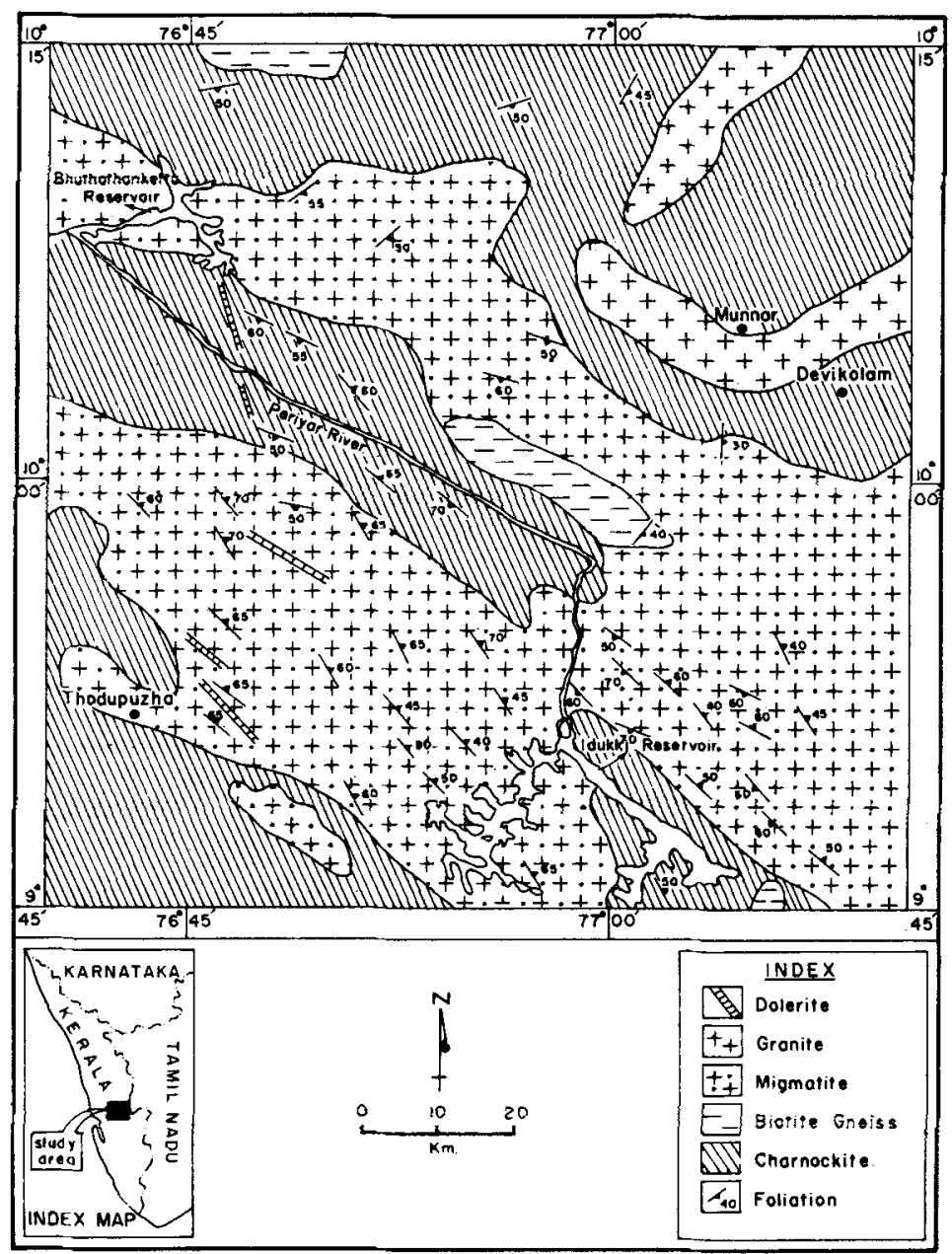

Figure 1. Generalised geological map of Central Kerala.

geology, though it is well established that the charnockites and gneisses form the earliest rock types of the Archean terrain, which have been extensively reactivised during the geologic history (Rao 1976). Occurrences of various acid intrusives along probable palaeo-rift zones are also recognised (Santosh and Nair 1983a; Santosh et al 1983). These intrusives are suggested to represent a Late Precambrian-Early Paleozoic taphrogenic acid magmatic regime (Santosh and Nair 1983b).

Although literature pertaining to the geology of this region mentions the occurrence of the gneisses, no systematic studies have been undertaken till now to understand their petrochemical significance in relation to regional tectonics. The present study is hence a preliminary effort to elucidate the geochemical characters of the gneisses of Central Kerala which are classified here as diatexites (Mehnert 1968) and to suggest a model for their evolution based on petrogenetic aspects. 


\section{Mineralogy}

The gneisses comprise fine-to-medium grained quartzo-feldspathic pink and grey migmatites. Generally, they exhibit development of a weak to strong foliation and mineralogical banding as a result of variation in the proportion of felsic and mafic constituents. Although phlebitic and stromatic structures and leucocractic seggregations are locally present, the gneisses generally exhibit schlieric and nebulitic structures tending towards a homophanous nature and are hence grouped here as the diatexite variety of migmatites (Mehnert 1968), which represent products of complete or nearly complete partial melting.

In some localities, mafic protoliths (or palaeosomes) of varying dimensions having calcic-plagioclase and hornblende as dominant minerals with high amounts of apatite and $\mathrm{Fe}-\mathrm{Ti}$ oxides are noted. Along the permeable weak zones of these protoliths, injections of leucoctatic material of granitic composition are common. In addition to the protoliths, elongated and lenosidal enclaves of 'refractory biotite' aggregates are also noted in several localities.

The general mineral assemblage comprises quartz, K-feldspar, oligoclase, biotite and hornblende. The quartz-K-feldspar-oligoclase, mosaic varies from inequigranular to equigranular and granoblastic. The $\mathrm{K}$-feldspar grains are commonly perthitic (figures $2 \mathrm{a}, \mathrm{b}$ and $\mathrm{c}$ ) and corresponds to the coarse 'mesoperthite' variety. At the plagioclase-Kfeldspar interfaces, worm-like myrmekitic intergrowths are locally developed (figure 2e). Biotite and hornblende usually show irrational interfaces. Part of biotites in gneisses appears to be product of homoaxial replacement of hornblende (figure $2 \mathrm{f}$ ) denoting retrogression of granulite facies assemblage and reequilibration under amphibolite facies conditions. Associated with the replacement of hornblende are seen secondary calcite and epidote. The accessories include Fe-Ti oxides, apatite, zircon, epidote and sphene. Biotite also forms fresh discrete laths which are strongly pleochroic.

\section{Geochemistry}

Major and trace element geochemistry of ten representative samples of the gneisses are presented in table 1, where they are compared with analysis of Precambrian gneisses and greywackes. Major elements were determined by conventional wet methods. $K$ and $\mathrm{Na}$ were analysed by flame photometer. Trace elements were determined by atomic absorption spectrophotometer (Perkin-Elmer 4000).

The $\mathrm{SiO}_{2}$ content shows a moderate variation from 61.5 to 71.38 with a mean at 67.8 . $\mathrm{Al}_{2} \mathrm{O}_{3}$ varies from $14 \cdot 1$ to $18 \cdot 35$ (av. $15 \cdot 7$ ), and the heterogeneity in the alumina: alkali distribution in the gneisses is displayed by the occurrences of normative corundum in some analysis (table 2). $\mathrm{K}_{2} \mathrm{O}$ values are high (up to 6.16) and $\mathrm{K}_{2} \mathrm{O}$ vs $\mathrm{Na}_{2} \mathrm{O}$ plots (Harpum 1963) fall in the field of adamellite (figure 3a). They also fall in the adamellite field in a normative feldspar ternary (figure 3b, after O'Conner 1965). $\mathrm{Na}_{2} \mathrm{O}$ (av. 3.53) $\mathrm{CaO}(2.44)$ and $\mathrm{MgO}$ (av. 0.93) levels are lower. Overall the major element geochemistry is comparable with the potassic members of Uivak gneisses (Bridgwater and Collerson 1976).

The variation in major element levels with respect to $\mathrm{SiO}_{2}$ is shown in figure 4 where all the elements (except $\mathrm{K}_{2} \mathrm{O}$ ) show relatively smcoth trends of depletion. The higher 



Figure 2. Photomicrographs of the gneiss (a), (b) and (c) varied perthitic texture with perthite lamellae ranging from fine to coarse. (d) Subhedral plagioclase showing lamella $r$ twinning and quartz. (e) Myrmeckite at the grain boundary of K-feldspar. (f) Retrogression of hornblende and development of biotite. 
levels of $\mathrm{K}_{2} \mathrm{O}$ with higher $\mathrm{SiO}_{2}$ probably indicate secondary $\mathrm{K}$-enrichment which is also evidenced by the occurrences of myrmekite at the interfaces of $\mathrm{K}$-feldspar and plagioclase. The smooth decreasing trend of $\mathrm{Al}_{2} \mathrm{O}_{3}$ and its sympathetic relationship with the distribution of $\mathrm{Na}_{2} \mathrm{O}$ and $\mathrm{CaO}$ indicate a dominant phase of plagioclase fractionation. Similar relations exist between $\mathrm{MgO}, \mathrm{FeO}$ and $\mathrm{TiO}_{2}$ consistent with the fractionation of mafic phases, mainly hornblende and biotite plots in a $\mathrm{Ca} / \mathrm{Ca}+\mathrm{Mg} v s$ $\mathrm{Fe} / \mathrm{Fe}+\mathrm{Mg}$ diagram (after Halloway 1971) fall in the igneous field (figure 5).

Among the trace elements, the high Ba values (up to $1354 \mathrm{ppm}$ ) and low Sr levels (av. $17 \mathrm{ppm}$ ) are typical. Trace element variations with respect to the index of differentiation, $\mathrm{Mg} / \mathrm{Mg}+\mathrm{Fe}^{\mathrm{t}}$ are shown in figure 6. The decreasing trends shown by $\mathrm{Ni}, \mathrm{Cr}, \mathrm{Li}$ and $\mathrm{V}$ with decrease in $\mathrm{Mg} / \mathrm{Mg}+\mathrm{Fe}^{\mathrm{t}}$ levels convey that fractionation of mafic phases was significant. The depletion of $\mathrm{Sr}$ is consistent with its accommodation in plagioclase. Since $\mathrm{Sr}$ levels are too low, even with high $\mathrm{Mg} / \mathrm{Mg}+\mathrm{Fe}^{\mathrm{t}}$ values, it has to be assumed that initially there had been extensive plagioclase fractionation and separation. Ba and $\mathrm{Pb}$, on the contrary, exhibit higher levels with high $\mathrm{Mg} / \mathrm{Mg}+\mathrm{Fe}^{\mathrm{t}}$ values which indicate their progressive concentration in the melt. Subsequently, as the crystallization of Kfeldspar (and/or biotite) started, they began to deplete yielding decreasing trend with increasing fractionation.

Table 1. Major and trace element geochemistry of the diatexites compared with analyses of Precambrian gneisses and greywacke.

\begin{tabular}{|c|c|c|c|c|c|c|c|}
\hline & MG-1 & MG-2 & MG-3 & MG-4 & MG-5 & MG-6 & MG-7 \\
\hline \multicolumn{8}{|c|}{ Major elements (wt. \%) } \\
\hline $\mathrm{SiO}_{2}$ & 69.08 & $61 \cdot 50$ & $71 \cdot 38$ & $65 \cdot 32$ & $70 \cdot 70$ & 66.64 & $70 \cdot 31$ \\
\hline $\mathrm{TiO}_{2}$ & 0.60 & 0.84 & 0.26 & 0.47 & 0.71 & 0.64 & $0 \cdot 34$ \\
\hline $\mathrm{Al}_{2} \mathrm{O}_{3}$ & $15 \cdot 30$ & $18 \cdot 35$ & $15 \cdot 37$ & $15 \cdot 80$ & $14 \cdot 10$ & $15 \cdot 28$ & $14 \cdot 32$ \\
\hline $\mathrm{Fe}_{2} \mathrm{O}_{3}$ & 0.88 & $2 \cdot 48$ & 1.00 & 2.00 & $2 \cdot 31$ & $2 \cdot 71$ & $2 \cdot 39$ \\
\hline $\mathrm{FeO}$ & $2 \cdot 08$ & 1.29 & 0.83 & $2 \cdot 37$ & 1.80 & $2 \cdot 37$ & 1.08 \\
\hline $\mathrm{MnO}$ & 0.01 & 0.03 & 0.02 & 0.05 & 0.04 & 0.05 & 0.05 \\
\hline $\mathrm{MgO}$ & 0.96 & 0.80 & 0.64 & 1.44 & 0.64 & $1 \cdot 28$ & $0-48$ \\
\hline $\mathrm{CaO}$ & 2.46 & $3 \cdot 14$ & 1.79 & $3 \cdot 36$ & $1 \cdot 79$ & $2 \cdot 69$ & $1 \cdot 34$ \\
\hline $\mathrm{Na}_{2} \mathrm{O}$ & $3 \cdot 32$ & $4 \cdot 21$ & 3.44 & $3 \cdot 60$ & $3 \cdot 33$ & $3 \cdot 35$ & $3 \cdot 21$ \\
\hline $\mathrm{K}_{2} \mathrm{O}$ & $4 \cdot 67$ & $6 \cdot 16$ & 3.89 & $4 \cdot 75$ & 5.00 & 3.71 & $4 \cdot 83$ \\
\hline $\mathrm{P}_{2} \mathrm{O}_{5}$ & 0.08 & 0.12 & $0-03$ & 0.15 & 0.09 & 0.06 & 0.02 \\
\hline Moisture & 0.18 & 0.14 & 0.15 & 0.18 & $0 \cdot 16$ & $0-14$ & 0.11 \\
\hline L.O.I. & 0.34 & $0-12$ & 0.20 & 0.71 & 0.15 & 0.21 & $0 \cdot 13$ \\
\hline \multicolumn{8}{|c|}{ Trace elements (ppm) } \\
\hline $\mathrm{Ba}$ & 958 & 578 & 444 & 1286 & 722 & 726 & 744 \\
\hline $\mathbf{B i}$ & 40 & 24 & 56 & 26 & 28 & 74 & 58 \\
\hline $\mathrm{Cr}$ & 78 & 98 & 44 & 98 & 44 & 156 & 66 \\
\hline $\mathrm{Cu}$ & 7 & 6 & 1 & 3 & 3 & 21 & 1 \\
\hline $\mathbf{L i}$ & 14 & 7 & 5 & 10 & 8 & 8 & 4 \\
\hline $\mathrm{Ni}$ & 34 & 40 & 12 & 36 & 14 & 44 & 28 \\
\hline $\mathrm{Pb}$ & 32 & 13 & 17 & 20 & 3 & 17 & 10 \\
\hline Sr & 6 & 14 & 8 & 16 & 10 & 18 & 10 \\
\hline V & 80 & 40 & 40 & 60 & 40 & 100 & 60 \\
\hline $\mathrm{Zn}$ & 33 & 17 & 23 & 67 & 58 & 159 & 130 \\
\hline
\end{tabular}


Table 1. (contd.)

\begin{tabular}{|c|c|c|c|c|c|c|c|c|}
\hline & MG-8 & MG-9 & MG-10 & Mean (1) & Mean (2) & Mean (3) & Mean (4) & Mean (5) \\
\hline \multicolumn{9}{|c|}{ Major Elements (wt. \%) } \\
\hline $\mathrm{SiO}_{2}$ & $71 \cdot 10$ & $68 \cdot 28$ & $62 \cdot 70$ & 67.80 & 67.20 & $65 \cdot 40$ & $70-05$ & $61 \cdot 70$ \\
\hline $\mathrm{TiO}_{2}$ & 0.24 & 0.47 & 0.51 & 0.51 & 0.76 & 0.50 & $1 \cdot 14$ & 0.40 \\
\hline $\mathrm{Al}_{2} \mathrm{O}_{3}$ & $15 \cdot 35$ & $15 \cdot 88$ & $17 \cdot 33$ & $15 \cdot 70$ & 13.46 & $16 \cdot 00$ & $11 \cdot 41$ & $14 \cdot 60$ \\
\hline $\mathrm{Fe}_{2} \mathrm{O}_{3}$ & $2 \cdot 84$ & 2.64 & $2 \cdot 71$ & $2 \cdot 20$ & 5.99 & 4.90 & $2 \cdot 64$ & 5.10 \\
\hline $\mathrm{FeO}$ & $0: 54$ & $1 \cdot 22$ & $2 \cdot 23$ & $1.58\}$ & & & 2.46 & \\
\hline $\mathrm{MnO}$ & 0.06 & 0.05 & 0.05 & 0.04 & $\ldots$ & $\cdots$ & 0.06 & . \\
\hline $\mathrm{MgO}$ & 0.94 & 0.80 & 1.28 & 0.93 & 0.99 & $2 \cdot 10$ & $2 \cdot 64$ & $3 \cdot 50$ \\
\hline $\mathrm{CaO}$ & 1.79 & $1 \cdot 57$ & $4 \cdot 48$ & 2.44 & $2 \cdot 71$ & 3.40 & 3.57 & $5 \cdot 70$ \\
\hline $\mathrm{Na}_{2} \mathrm{O}$ & $3 \cdot 35$ & $3 \cdot 32$ & $4 \cdot 16$ & 3.53 & 3.80 & 3.90 & $2 \cdot 68$ & $4 \cdot 10$ \\
\hline $\mathrm{K}_{2} \mathrm{O}$ & 4.93 & 4.88 & 3.64 & $4 \cdot 64$ & $4 \cdot 07$ & $2 \cdot 80$ & $1 \cdot 18$ & 1.90 \\
\hline $\mathrm{P}_{2} \mathrm{O}_{5}$ & 0.06 & 0.04 & $0 \cdot 13$ & 0.08 & . & . & 0.21 & . \\
\hline Moisture & 0.14 & 0.12 & 0.13 & $0 \cdot 15$ & . & $\ldots$ & . & . \\
\hline L.O.I. & 0.20 & 0.21 & 0.18 & 0.25 & . & . & . & . \\
\hline \multicolumn{9}{|c|}{ Trace Elements (ppm) } \\
\hline $\mathbf{B a}$ & 1354 & 824 & 514 & 815 & & & & \\
\hline $\mathrm{Bi}$ & 62 & 82 & 82 & 53 & & & & \\
\hline $\mathrm{Cr}$ & 58 & 68 & 108 & 82 & & & & \\
\hline $\mathrm{Cu}$ & 1 & 3 & 14 & 6 & & & & \\
\hline $\mathrm{Li}$ & 8 & 6 & 6 & 8 & & & & \\
\hline $\mathrm{Ni}$ & 22 & 24 & 44 & 30 & & & & \\
\hline $\mathrm{Pb}$ & 19 & 14 & 11 & 16 & & & & \\
\hline Sr & 24 & 12 & 50 & 17 & & & & \\
\hline $\mathbf{V}$ & 120 & 40 & 80 & 66 & & & & \\
\hline $\mathrm{Zn}$ & 80 & 83 & 32 & 68 & & & & \\
\hline
\end{tabular}

Mean (1)-Mean of 10 analyses of present study.

Mean (2)-Potash-rich Uivak gneiss (Bridgwater and Collerson 1976 Table 1); mean (3)-Banded gneisses and migmatites (Eade and Fahrig 1971, table 21); Mean (4)-Biotite-hornblende gneisses (Janardhan et al 1978, table 2); Mean (5) - Greywackes from Chitaldurg (Naqvi 1977).
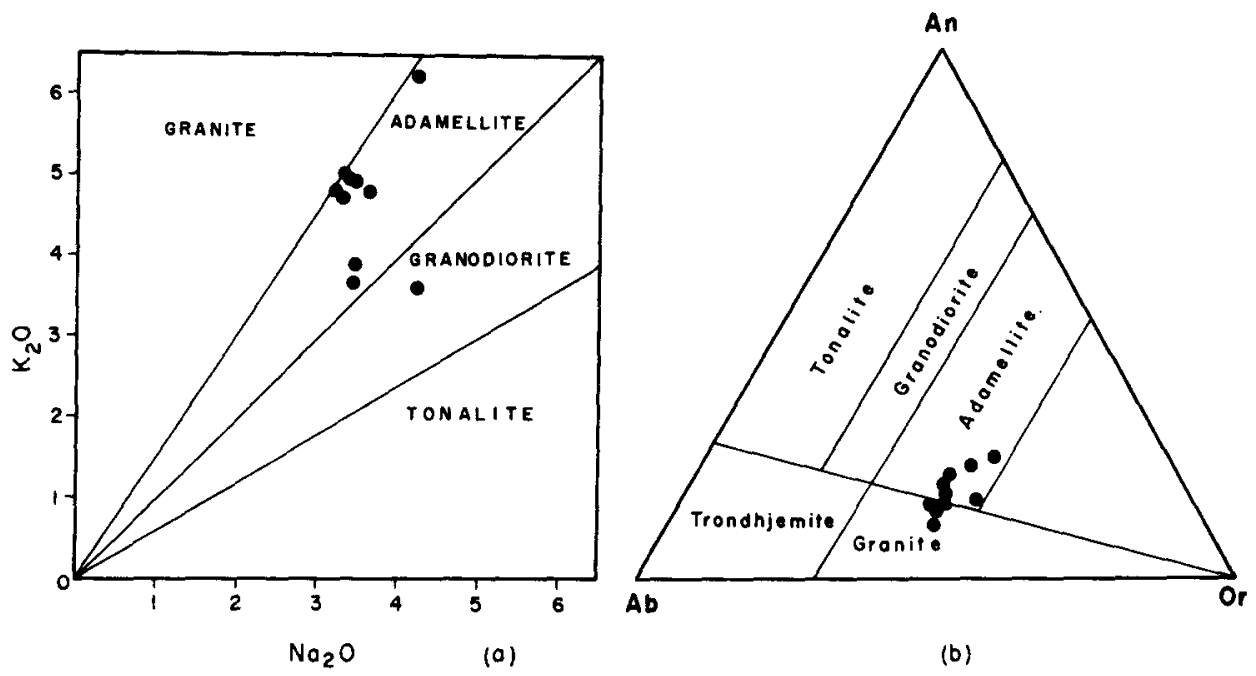

Figure 3. Classification of the gneisses (a) $\mathrm{K}_{2} \mathrm{O}$ is $\mathrm{Na}_{2} \mathrm{O}$ plots (after Harpum 1963). (b) Normative feldspar plots (after O'Conner 1965). 


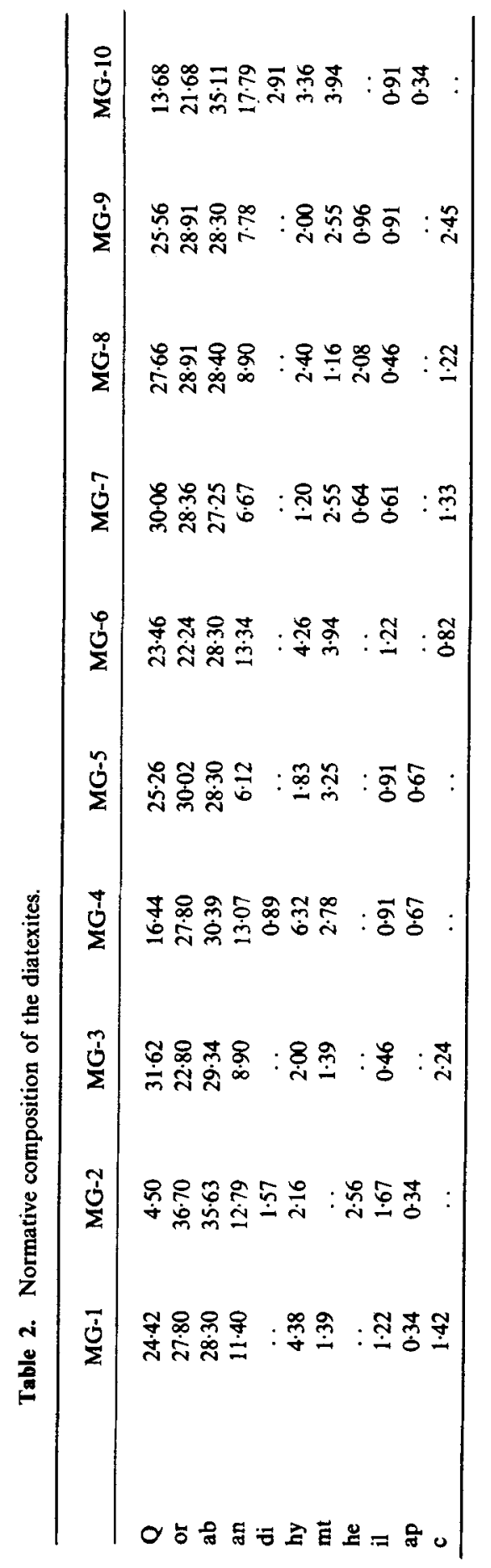




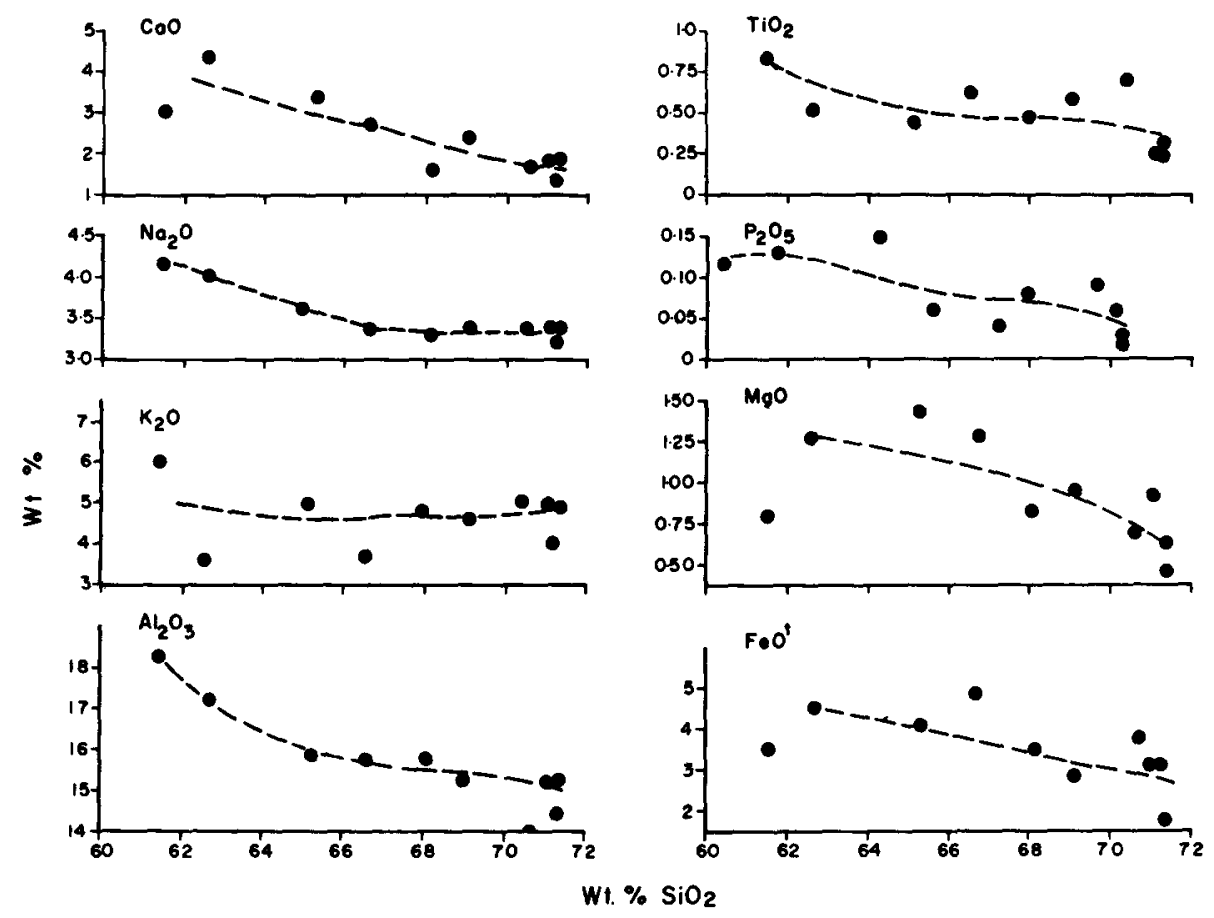

Figure 4. Harker variation of major elements.

\section{Petrogenesis}

The diatexites of Central Kerala resemble the biotite hornblende gneisses of Sargur Schist Complex, considered similar to the Peninsular gneisses around Bangalore, which has been observed to be products of migmatisation of hornblende granulites (Janardhan et al 1978).

It is now widely accepted that Archean gneissic complexes had an igneous origin and the igneous precursor for them may be either a volcanic succession dominated by dacitic rocks or intrusive plutons (Condie 1981). Anatexis, migmatisation and Kmetasomatism in such terrains are significantly younger than the igneous event (Bridgwater and Collerson 1976). Tonalites and trondhjemites are modelled to be the products of fractional crystallization of magmas produced by about $20 \%$ partial melting of Archean tholelitic basalt metamorphosed to amphibolite or eclogite (Arth and Hanson 1972; Arth and Barker 1976). The quartz monzonites and granodiorites of the Barberton region, South Africa, are conceived to have formed by $70-80 \%$ fractional crystallization of a granodioritic magma derived by the partial melting of siliceous granulites (Condie and Hunter 1976). Similarly, geochemical modelling of the Louis Lake batholith, Wyoming show that the Precambrian granodioritic and quartz monzonitic rocks were derived from a parent granodioritic magma involving hydrous partial melting of quartz eclogite in the upper mantle (Condie and Lo 1971). Collerson and Bridgwater (1979) recognised the potassic members of Uivak gneissic suite, Saglek 


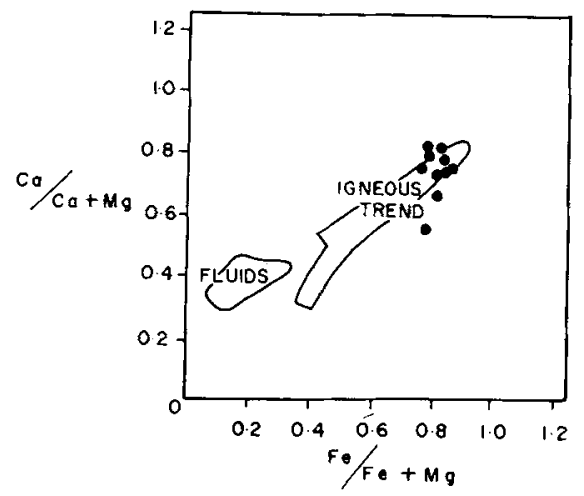

Figure 5. $\mathrm{Ca} / \mathrm{Ca}+\mathrm{Mg}$ vs $\mathrm{Fe} / \mathrm{Fe}+\mathrm{Mg}$ plots. The igneous trend is from Halloway (1971).
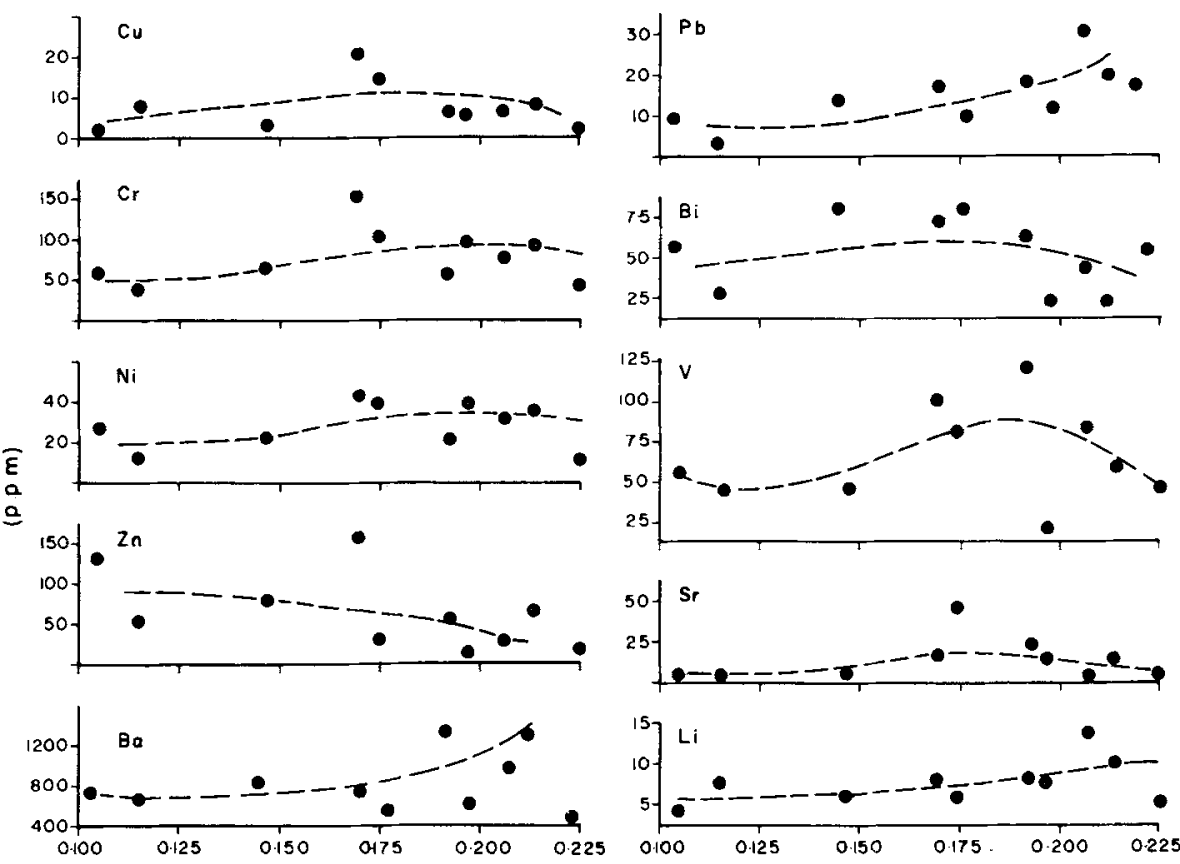

$\mathrm{Mg} / \mathrm{Mg}+\mathrm{Fe}^{\dagger}$

Figure 6. Trace element variations against $\mathrm{Mg} / \mathrm{Mg}+\mathrm{Fe}^{\mathrm{t}}$.

area, Labrador, to be the products of partial melting of tonalites and trondhjemites under granulite facies conditions.

The mineral assemblage of the diatexites could be explained in terms of a simple model involving partial melting of greywackes (Winkler 1974) with the high $\mathrm{K}_{2} \mathrm{O}$ values probably suggesting mixing of greywackes with pelites or psammopelites. However, the geochemical characters of the diatexites including their fractionated nature, the association of mafic protoliths and the occurrence of the diatexites in the 
Table 3. Schematic model showing the evolution of the diatexites.

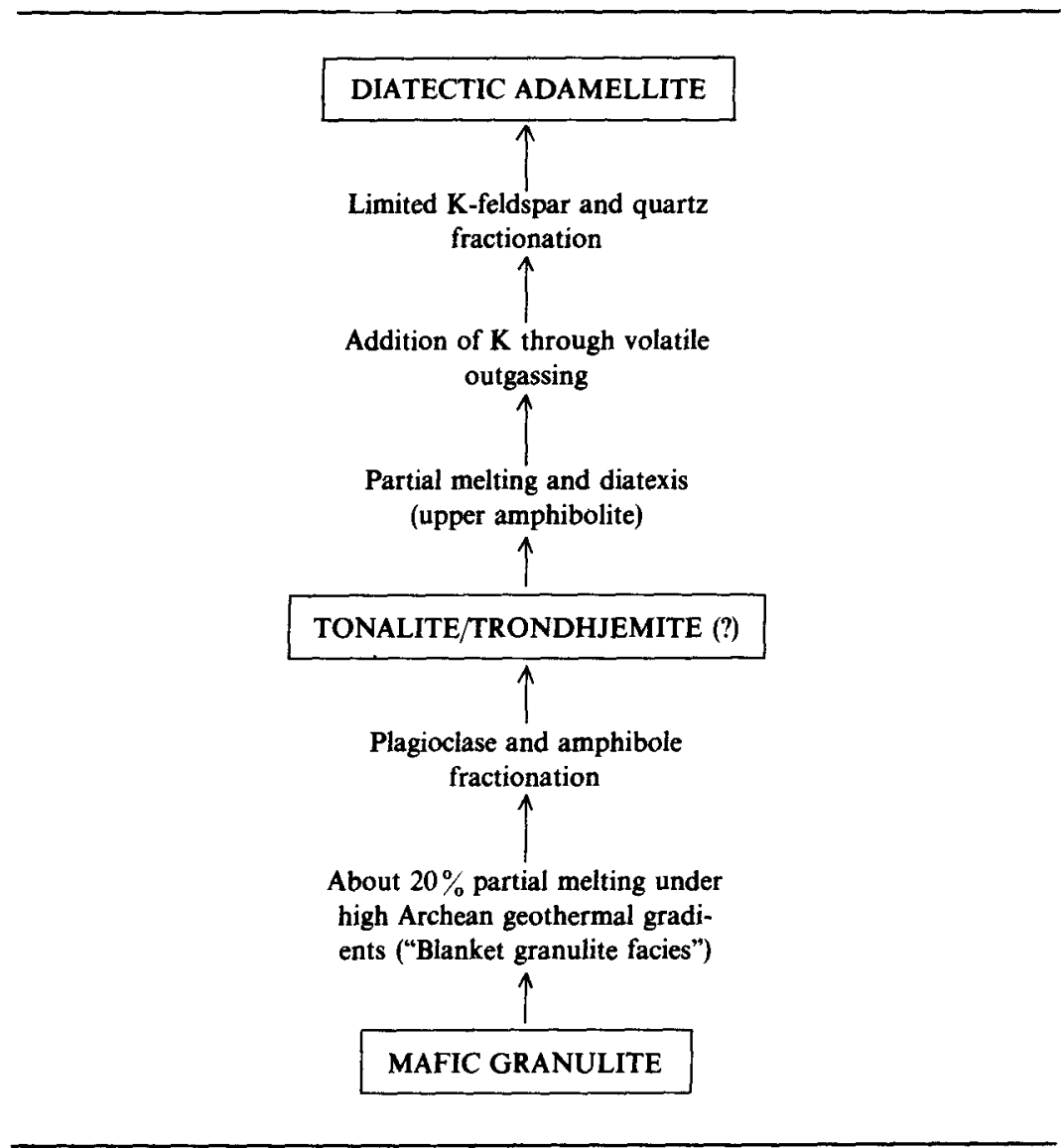

granulitic mobile belt along major rift-lineaments favour an igneous parentage. Moreover, greywackes are noted to be conspicuously absent in charnockite and high grade gneiss terranes (Iyer and Kutty 1978). The biotite-hornblende gneisses of the Eastern Ghats belt in general were earlier assumed to be products of retrogression of associated charnockites. However, recent studies including detailed geochemical assessments (Iyer and Kutty 1978) show that these gneisses are not the products of charnockite retrogression.

For the evolution of gneisses of Central Kerala, a two-stage model is proposed (table 3), which envisages mafic granulites as the starting material (Wyllie 1977) and not quartz eclogite or amphibolite as conceived by Condie and Lo (1971) and Condie and Hunter (1976). It has been shown (Collerson and Fryer in Collerson and Bridgwater 1979) that under the influence of high Archean geothermal gradients, partial melting of eclogite or amphibolite would not take place since granulite facies assemblages would exist under the $\mathrm{P}, \mathrm{T}$ conditions where melting could occur. Since mafic granulites are the starting material, a small degree of hydrous partial melting at intermediate depths will yield trondhjemitic and tonalitic magmas (Wyllie 1977) in contrast to the granodioritic magma from quartz eclogites (Condie and Lo 1971). This warrants a two-stage model 
in the present case for the petrogenetic evolution to adamellite (quartz mozonite) and granodiorite. The melting of mafic granulites were achieved under the high Archean geothermal gradients of probably more than $100^{\circ} \mathrm{C} / \mathrm{km}$ (Fyfe 1973) and is assumed to be synchronous with the 'blanket granulite facies metamorphism' recognised as part of the earliest tectonomagmatic event in the Kerala region (Rao 1976). The melt was fractionated mainly with respect to plagioclase and hornblende as evidenced from the highly Sr-depleted character, the occurrence of mafic protoliths representing the feldspar-amphibole residue and the presence of hornblende as the dominant mafic fraction in the gneisses. Plots in A-F-M and K-Na-Ca diagrams indicate calc-alkaline differentiation trends (figure 7). Subsequently, the geothermal gradients decreased with time, probably to values less than $60^{\circ} \mathrm{C} / \mathrm{km}$ and hence during the second phase of



Figure 7. A-F-M (a) and $\mathrm{K}-\mathrm{Na}-\mathrm{Ca}$ (b) plots of the gneisses. The trend lines are from Barker and Arth (1976).

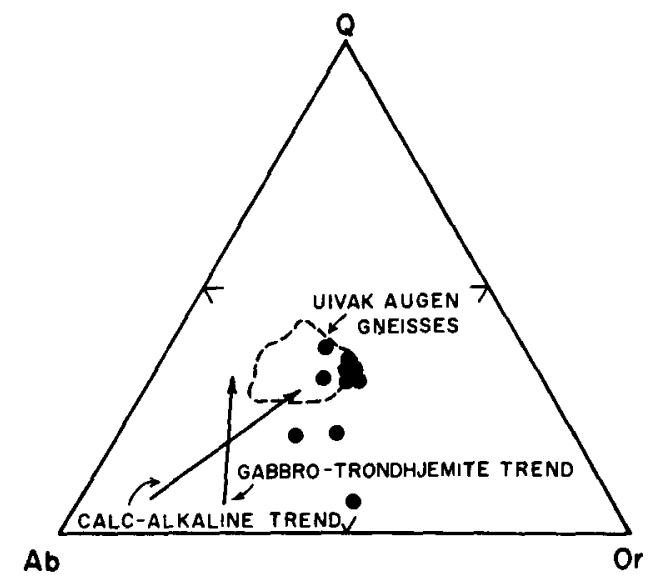

Figure 8. Q-Ab-Or plots. The field of Uivak augen gneisses is after Collerson and Bridgewater (1979). The calcalkaline and gabbro-trondhjemite trends are from Barker and Arth (1976). 
tectogenesis, an amphibolite facies partial melting could develop (Wyllie 1977), the retrogressive effect of which is observed in the development of fresh biotite from altered hornblende. Such amphibolite facies overprinting on the original granulite facies is already recognised in this region ( $c f$ Rao 1976). The melting of sialic components was nearly complete resulting in the schlieric and nebulitic or nearly homophanous nature of the rock, designated as diatexites (Mehnert 1968). Anatectic melting left the refractory of 'biotite restite' within the gneisses.

Synchronous with the anatexis, or to be precise, diatexis, $\mathrm{K}$-enrichment took place through volatile influx which modified the chemistry resulting in higher $\mathrm{K}_{2} \mathrm{O} / \mathrm{Na}_{2} \mathrm{O}$ ratios, warranting an adamellitic classification. This is quite similar to the phenomena recognised for the origin of the potassic members of the Uivak gneisses of Labrador (Collerson and Bridgwater 1979). In this context, it is interesting to note that the two major gneissic terrains in central and northern Kerala occur along major lineaments of the region, the Periyar and Idamalayar lineaments of Central Kerala and the Bavali lineament of northern Kerala. These lineaments are known to be deep-seated fractures representing rift zones which have been reactivated from time to time. These fractures are also suggested to have served as conduits for large scale volatile-influx, responsible for the generation and emplacement of magmatic rock suites (Nair and Santosh $1983 a, b)$.

The derivation of adamellite from the diatectic melt was achieved through limited degree of (metamorphic) differentiation. The decreasing trends exhibited by $\mathrm{Ba}$ and $\mathrm{Pb}$ and the overall decrease in the $\mathrm{Ba} / \mathrm{Sr}$ ratio is consistent with $\mathrm{K}$-feldspar fractionation (Hanson 1978). In a Q-Ab-Or diagram (figure 8) the plots progressively tend towards the Q-apex consistent with fractionation involving alkali feldspar and quartz. The similarity of the plots to the field of Uivak augen gneisses and overall parallelism with the gabbro trondhjemite trend (Barker and Arth 1976) are also consistent with the assumed model of evolution of the gneisses.

\section{Acknowledgements}

The study forms part of the project 'Long term environmental and ecological impact of multipurpose river valley projects-Comprehensive studies in the Western Ghats'. The authors are thankful to Department of Environment, Govt. of India, for financial assistance. They also thank Dr. Harsh K Gupta, for providing facilities.

\section{References}

Arth J G and Hanson G N 1972 Contrib. Mineral. Petrol. 37161

Arth J G and Barker F 1976 Geology 4534

Barker F and Arth J G 1976 Geology 4596

Bridgwater D and Collerson K D 1976 Contrib. Mineral. Petrol. 5443

Collerson K D and Bridgwater D 1979 in Trondhjemites, dacites and related rocks (ed.) F Barker (Amsterdam: Elsevier) p. 205

Condie K C 1981 Archean greenstone belts (Amsterdam: Elsevier) 434 p

Condie K C and Hunter D R 1976 Earth Planet. Sci. Lett. 29389

Condie K C and Lo H H 1971 Geochim. Cosmochim. Acta 351079

Eade K E and Fahrig W F 1971 Bull. Geol. Surv. Canada 17951

Fyfe W S 1973 Philos. Trans. R. Soc. London A273 457

Halloway J R 1971 Geol. Soc. Am. Bull. 82233 
Hanson G N 1978 Earth Planet. Sci. Lett. 3826

Harpum J R 1963 Rec. Geol. Surv. Tanganyika 1087

Iyer A G V and Kutty N T R 1978 in Archaean geochemistry B F Windley and S M Naqvi (eds) (Amsterdam: Elsevier) p. 269

Janardhan A S, Srikantappa C and Ramachandra H M 1978 in Archaean geochemistry (eds) B F Windley and S M Naqvi (Amsterdam: Elsevier) p. 127

Mahadevan T M 1964 Proc. Int. Geol. Cong. 22 Sess. III 88

Mehnert K R 1968 Migmatites and the origin of granitic rocks (Amsterdam: Elsevier) 393 p

Nair N G K and Santosh M 1983a Proc. Indian Acad. Sci. (Earth Planet. Sci.) 92129

Nair N G K and Santosh M 1983b J. Geol. Soc. India (in press)

Naqvi S M 1977 Bull. Geophys. Res. 1517

O'Conner J T 1965 U.S. Geol. Surv. Prof. pap. 525-B

Rao P S 1976 Seminar on Geology and Geomorphology Kerala (Abstr) Geol. Surv. India

Santosh M 1981 Geology and tectonics of Periyar-Thodupuzha drainage basins, Kerala Report D.O.E.

Project-I (unpub.) Centre for Earth Science Studies $11 \mathrm{p}$

Santosh M and Nair N G K 1983a J. Geol. Soc. India 24291

Santosh M and Nair N G K 1983b Proc. Indian Acad. Sci. (Earth Planet. Sci.) 92297

Santosh M and Rajan P K 1982 Geology of Periyar-Thodupuzha drainage basins Kerala, Report D.O.E. Project-I (unpub.), Centre for Earth Science Studies. $16 \mathrm{p}$

Santosh M, Rajan P K and Nair N G K 1983 Bull. Indian Geol. Assoc. 1633

Winkler H G F 1974 Petrogenesis of metamorphic rocks (New York: Springer-Verlag) 334 p

Wyllie P J 1977 Tectonophysics 4341 